\title{
Two surgeons and the ECG: a double blind study?
}

\author{
Ulf Martin Schilling \\ From Danish Society for Emergency Medicine: Research Symposium 2010 \\ Roskilde, Denmark. 20-21 May 2010
}

\section{Background}

Among medical doctors, an old saying is that two surgeons and an ECG form a double-blind-study. To our knowledge, this prejudice was never controlled scientifically. This is the first study to assess the capability of operating abdominal and orthopaedic surgeons to analyze a set of standardized ECG.

\section{Methods}

30 operating abdominal and orthopaedic surgeons at our university hospital were directly approached to volunteer for this study. Each participant analyzed a set of five standardized ECG with an answering scheme for eight different items, giving a maximum score of 40 . The answers were matched according to specialty and experience of the doctors of less than 5 years, between 5 and 10 years or more than 10 years. The reference standard was set by two independent consultants in cardiology. All answers recollected within three months were included in the study.

Only correctly assessed items were accepted, unanswered items were regarded as incorrect. Statistical analysis was performed by the Student's T-test and confidence intervals were calculated at $95 \%$. Probability (p) levels of $<0.05$ were accepted as significant.

\section{Results}

Twenty answers could be included, 12 from orthopaedic and 8 from abdominal surgeons. The mean overall score was $25.25(63.13 \% \pm 4.78 \%)$ varying between $38(95 \%)$ and $20(50 \%)$.

Abdominal surgeons performed a mean score of $27.625(69.06 \% \pm 9.53 \%)$, and orthopaedic surgeons 23.67 points $(59.17 \% \pm 3.69 \%)$. The difference between

Correspondence: mschillingdeu@netscape.net

Department of accidents and emergencies, Linköpings university hospital, Sweden the performance of abdominal and orthopaedic surgeons was not significant $(p=0.09)$. Experienced surgeons seemed to perform slightly better than junior colleagues but no significant difference could be found among the subgroups. 20/20 surgeons identified ST-elevation myocardial infarction (STEMI) and no surgeon accepted the ECG showing acute STEMI as normal.

\section{Conclusion}

Abdominal and orthopaedic surgeons provided an answering scheme are able to interprete the ECG and identify both the normal and the ECG showing lifethreatening pathology. The hypothesis that surgeons were unable to interprete the ECG must be rejected.

Published: 17 September 2010

doi:10.1186/1757-7241-18-S1-P38

Cite this article as: Schilling: Two surgeons and the ECG: a double blind study? Scandinavian Journal of Trauma, Resuscitation and Emergency

Medicine 2010 18(Suppl 1):P38.
Submit your next manuscript to BioMed Central and take full advantage of:

- Convenient online submission

- Thorough peer review

- No space constraints or color figure charges

- Immediate publication on acceptance

- Inclusion in PubMed, CAS, Scopus and Google Scholar

- Research which is freely available for redistribution

Submit your manuscript at www.biomedcentral.com/submit
C Biomed Central 